\title{
Returning Samples from Enceladus for Life Detection
}

\section{Primary author:}

Marc Neveu - NASA Goddard Space Flight Center, Greenbelt, MD / University of Maryland, College Park, MD - Phone: +1 301-614-6872 - Email: marc.f.neveu@nasa.gov

\section{Co-authors:}

Ariel Anbar - Arizona State University, Tempe, AZ

Alfonso Davila - NASA Ames Research Center, Moffett Field, CA

Daniel P. Glavin - NASA Goddard Space Flight Center, Greenbelt, MD

Shannon M. MacKenzie - Johns Hopkins Applied Physics Laboratory, Laurel, MD

Charity Phillips-Lander - Southwest Research Institute, San Antonio, TX

Brent Sherwood - Blue Origin, Seattle, WA, USA

Yoshinori Takano - Japan Agency for Marine-Earth Science \& Technology, Yokosuka, Japan

Peter Williams - Arizona State University, Tempe, AZ

Hajime Yano - Institute of Space and Astronautical Science, Japan Aerospace Exploration

Agency, Sagamihara, Japan

\section{Co-signers:}

Jose Aponte - NASA Goddard Space Flight Center, Greenbelt, MD

Ellen Czaplinski - University of Arkansas, Fayetteville, AR

Simon Friesen - University of Waterloo, Ontario, Canada

Kosuke Fujishima - Earth Life Science Institute, Tokyo Institute of Technology, Tokyo, Japan

Julie Huber - Woods Hole Oceanographic Institution, Woods Hole, MA

Kim Reh - Jet Propulsion Laboratory, California Institute of Technology, CA

Christophe Sotin - Jet Propulsion Laboratory, California Institute of Technology, CA

Wataru Takahagi - The University of Tokyo, Bunkyo, Japan

Bethany Theiling - NASA Goddard Space Flight Center, Greenbelt, MD

Vassilissa Vinogradoff - CNRS, Aix-marseille University, PIIM, LAM, France

This white paper is an edited version of an eponymous paper by the same authors accepted for publication in Frontiers in Astronomy and Space Sciences: Neveu M, Anbar AD, Davila AF, Glavin DP, MacKenzie SM, Phillips-Lander CM, Sherwood B, Takano Y, Williams P and Yano H (2020) Returning Samples From Enceladus for Life Detection. Front. Astron. Space Sci. 7:26. doi: 10.3389/fspas.2020.00026. That publication is an open-access article distributed under the terms of a CC BY license authorizing use, distribution or reproduction provided it is cited and authors and copyright holders credited, as is done here. 


\section{Returning Samples from Enceladus for Life Detection - Key points:}

1. This white paper complements the Planetary Mission Concept Study (PMCS) report "Flagship Concepts for Astrobiology at Enceladus", which does not address sample return.

2. Sample return allows adaptation of analyses to prior findings, access to the full diversity of existing and future interrogation techniques, and time and resources to assess the validity of results. Previous experience has shown that all three aspects are crucial to life detection.

3. Sample return may require substantially less plume sample (milligrams $=a$ few flybys) than in situ investigations (grams) to perform life detection.

4. A Saturn orbiter flying about ten times through Enceladus' plume minimizes the mission duration to $\approx 15$ years, but the effect of collection at $\geq 1 \mathrm{~km} / \mathrm{s}$ must (and can) be minimized.

5. Technology developments are needed for sample collection and preservation, as well as for the implementation of Restricted Earth Return planetary protection policy for cold samples.

6. The ease of access of ocean material through the plume allows one to bypass the sequence of missions to "fly by, orbit, land, rove, and return samples".

7. The considerations discussed here could apply to other worlds when hints of erupted material are confirmed to be samples of a subsurface ocean, e.g., Europa (Roth et al. 2014), Ceres (Küppers et al. 2014), or Triton (Kirk et al. 1995).

\section{Why return samples from Enceladus for life detection?}

A world ripe for life detection. Saturn's tiny moon Enceladus has a subsurface ocean that sources plumes of water vapor and ice vented to space from its south polar terrain (SPT). The vented material provides the strongest evidence to date of a habitable world beyond Earth (Fig. 1) with liquid water, the major elements for life $\mathrm{H}, \mathrm{C}, \mathrm{N}, \mathrm{O}$, simple and complex organic compounds, bioavailable energy, and clement physicochemical conditions (Postberg et al. 2018).

This offers the chance to search for life in the plume.

Figure 1. Enceladus is farthest along the roadmap to ocean worlds (Hendrix, Hurford et al. 2019).

A scientific breakthrough. A positive detection could provide the first definitive evidence for life beyond

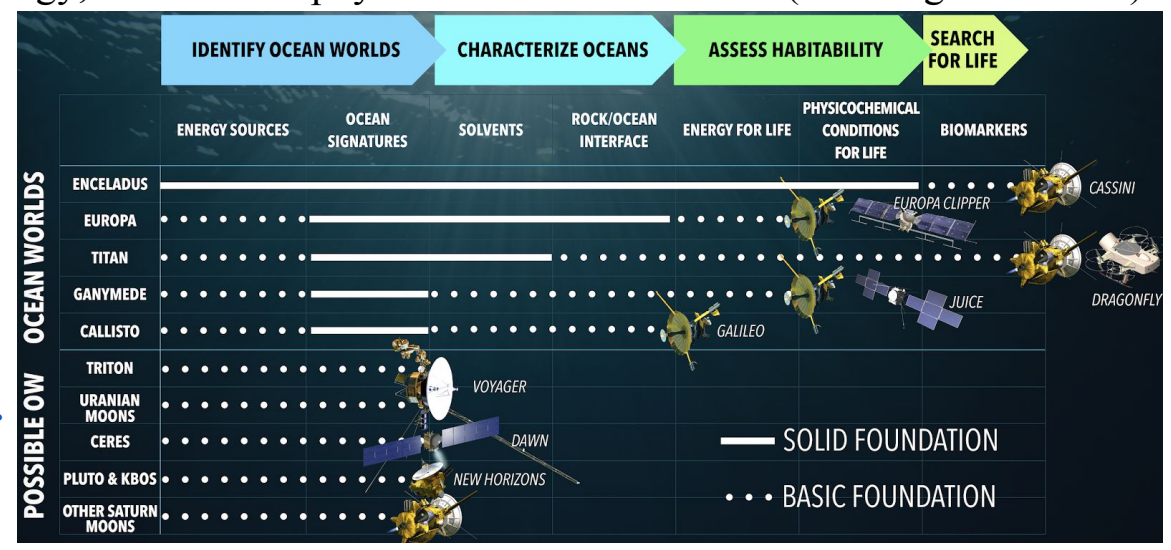
Earth, with a likely independent emergence given the dearth of material exchange between Enceladus and the inner Solar System (Worth et al. 2013). This would suggest biology is universal and provide a second data point to understand its nature. The alternative result could be the first habitat where signs of life are not detected, constraining the detectability of biospheres beyond Earth ( $f_{l}$ term in the Drake equation; Burchell 2006). 
Why sample return? Life detection mission concepts ranging from in situ (Lunine et al. 2015; MacKenzie et al. 2016; Eigenbrode et al. 2018), to orbiting or landing (MacKenzie et al. PMCS report), to sample return (Tsou et al. 2012; Sekine et al. 2014) have been proposed or discussed. Returning samples of ejected ocean material comes with challenges (Section 3), but uniquely enables investigations that can be adapted as results are obtained, are exquisitely sensitive, and leverage progress in measurement capabilities for decades to come.

\begin{tabular}{|c|c|c|}
\hline Life detection... & In situ & In returned samples \\
\hline Advantages & $\cdot$ Contextual understanding $\quad$ Sample minimally altered & $\cdot$ Adaptable analyses $\cdot$ Unmatched instruments \\
\hline Drawbacks & $\begin{array}{c}\cdot \text { Inflexible measurement capabilities } \\
\cdot \text { Limited space-proof instruments }\end{array}$ & $\begin{array}{c}\cdot \text { Lack of contextual understanding } \\
\text {-Sample alteration between collection and measurement }\end{array}$ \\
\hline
\end{tabular}

Table 1. Relative merits of in situ and sample return missions for life detection.

Adaptable analyses. The path to every confirmed or refuted claim of life detection in samples of ancient (e.g., Schopf 1993), extraterrestrial (McKay et al. 1996), or otherwise secluded environments (Priscu et al. 1999) has taken years of subsequent, initially unplanned analyses. This is the time needed for cross-validation by other research teams, refutation of claims, or follow-on hypothesis-driven measurements, which proceed at the pace of journal publications. In this context, in situ life detection presents the risk that the payload finds tantalizing clues that it cannot confirm. As versatile as flight instruments can be, their capabilities are frozen-in at the time of design, years ahead of the measurements, with a preconception of what could be measured. With returned samples, the next measurement can be devised based on the results of the previous one, with ample time to think through the path of analysis. Laboratory measurements can be adapted to sample properties, repeated, and checked with complementary techniques.

The best instruments cannot be flown. For life detection, these include:

1. higher performance than can be flown at any given time (Table 2).

2. instruments that cannot be miniaturized, requiring a room or a facility (Fig. 2; Table 2).

3. complex wet chemistry protocols or sample preparation steps (Elsila et al. 2009),

4. a more diverse suite of techniques than could be accommodated on spacecraft.

Figure 2. Example techniques to search for life that cannot be flown. A. Secondary ion mass spectrometer for isotopic measurements on small

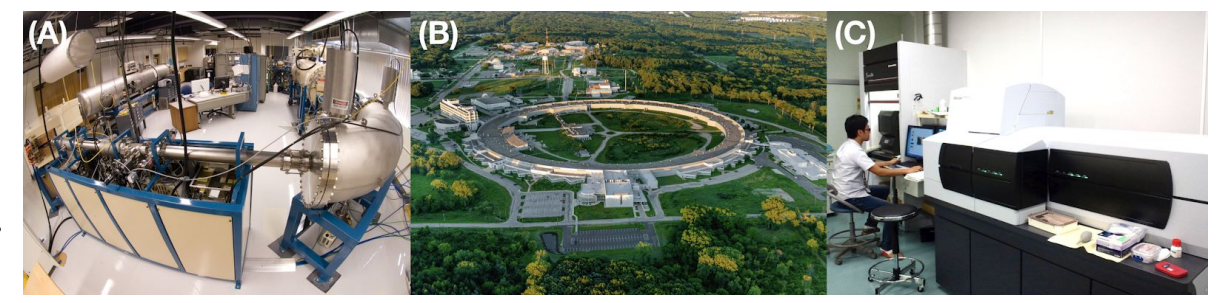
samples proximal to contamination, built for the Genesis mission. B. Synchrotron used, e.g., for micro X-ray diffraction. C. Matrix-assisted laser desorption / ionization-mass microscope.

Archival. Archiving part of returned material enables analyses with techniques that cannot be fathomed at the time of mission design. Analyses of archived Apollo lunar samples keep on yielding insights with new means of investigation (Shearer \& Borg 2006; Zeigler et al. 2019). 


\section{Measurement strategy, sample needed, and mission architectures}

The community has set a high bar: life must be the only possible explanation for the results (Neveu et al. 2018). To this end, life detection strategies target multiple attributes (potential "biosignatures") that distinguish biological from abiotic properties or processes (e.g., Hand et al. 2017; Neveu et al. 2018; Glavin et al. 2019). If life is not found, these measurements are crucial to find out how far toward life chemistry has progressed, reconstruct the sample's provenance (journey between synthesis and collection), and quantify how much biomass (if any) was expected. Example attributes, detection techniques, and corresponding amounts of solid sample needed (water ice with percent-level salts and organic compounds) are provided in Table 2.

\begin{tabular}{|c|c|c|c|c|}
\hline Biosignature & Example technique & Capability on Earth & Capability in situ & Sample needed \\
\hline $\begin{array}{l}\text { Over-representation of amino } \\
\text { acids of high molar mass and } \\
\text { structural isomeric preference }\end{array}$ & \multirow{4}{*}{$\begin{array}{l}\text { Mass spectrometry with } \\
\text { separation stage (e.g., } \\
\text { capillary electrophoresis, gas } \\
\text { or liquid chromatography) }\end{array}$} & $\begin{array}{l}\text { Abundances of amino acids of } \\
\text { mass } \leq 500 \text { atomic mass } \\
\text { units (amu) at } \geq 1 \mathrm{pmol} \mathrm{g}^{-1}\end{array}$ & $\begin{array}{l}\text { Abundances of amino acids of } \\
\text { mass } \leq 500 \text { amu at } \geq 1 \text { pmol } \\
g^{-1}(\text { ref. } 1,2)\end{array}$ & $0.1 \mathrm{~g}$ (in situ) (ref. 2) \\
\hline $\begin{array}{l}\text { Distribution of carbon chain } \\
\text { length in long-chain } \\
\text { hydrocarbons }\end{array}$ & & $\begin{array}{l}\text { Relative abundances of } \\
\text { hydrocarbons with mass } \leq 10^{4} \\
\text { amu present at } \geq 1 \mathrm{pmol} \mathrm{g}^{-1}\end{array}$ & \begin{tabular}{|l|} 
Relative abundances of \\
hydrocarbons $\leq 500 \mathrm{amu}$ at $\geq$ \\
$1 \mathrm{pmol} \mathrm{g}^{-1}$ (ref. 1,2$)$
\end{tabular} & $0.1 \mathrm{~g}$ (in situ) (ref. 2) \\
\hline $\begin{array}{l}\text { Distribution of the number of } \\
\text { types of operations needed to } \\
\text { build each organic molecule }\end{array}$ & & $\begin{array}{l}\text { Organic compounds } \leq 10^{4} \\
\text { amu at } \geq 1 \mathrm{fmol} \mathrm{g}^{-1} \text {, mass } \\
\text { resolution }>10^{5}-10^{6}\end{array}$ & $\begin{array}{l}\text { Organic compounds } \leq 1000 \\
\text { amu at } \geq 1 \mathrm{pmol} \mathrm{g}^{-1} \text {, mass } \\
\text { resolution } 1 \mathrm{amu} \text { (ref. 2) }\end{array}$ & $0.1 \mathrm{~g}$ (in situ) (ref. 2) \\
\hline $\begin{array}{l}\text { Enantiomeric excess in all } \\
\text { chiral amino acids }\end{array}$ & & $\begin{array}{l}\text { As above, plus relative molar } \\
\text { abundances of enantiomers of } \\
\text { amino acids with up to } 7 \mathrm{C} \\
\text { atoms at ppb levels (ref. } 3,4 \text { ) }\end{array}$ & $\begin{array}{l}\text { As above, plus relative molar } \\
\text { abundances of enantiomers of } \\
\text { amino acids at ppm levels } \\
\text { (ref. } 1,5)\end{array}$ & $\begin{array}{l}0.5 \mathrm{mg} \text { (sample return) (ref. } \\
6,7 \text { ) } \\
0.5 \mathrm{~g} \text { (in situ) (ref. } 2,7 \text { ) }\end{array}$ \\
\hline $\begin{array}{l}\text { Enantiomeric excess in all } \\
\text { chiral sugar compounds } \\
\text { (polyols) }\end{array}$ & $\begin{array}{l}\text { Liquid extraction, purification, } \\
\text { derivatization, and gas } \\
\text { chromatography (ref. } 4,8)\end{array}$ & $\begin{array}{l}\text { Relative abundances of } \\
\text { enantiomers of sugars with up } \\
\text { to } 6 \mathrm{C} \text { atoms (ref. } 4,8 \text { ) }\end{array}$ & $\begin{array}{l}\text { Cannot currently be } \\
\text { implemented (ref. 4) }\end{array}$ & $\begin{array}{l}\text { mg to g (sample return) (ref. } \\
4,9)\end{array}$ \\
\hline $\begin{array}{l}\text { Polymers with a repeating } \\
\text { charge in their backbone }\end{array}$ & Nanopore sequencing & $\begin{array}{l}\text { Identify and sequence DNA, } \\
\text { RNA, and other biopolymers } \\
\text { agnostically (ref. 10) from } \geq 1 \\
\text { ng polymer (ref. 11) }\end{array}$ & $\begin{array}{l}\text { Not yet fully established (ref. } \\
12 \text { ) }\end{array}$ & $\begin{array}{l}>1 \mathrm{~kg} \text { based on } \sim 100 \mathrm{ng} \text { DNA } \\
\text { (kg Earth ocean water })^{-1} \text { (ref. } \\
13 \text { ). Enceladus biomass }>10^{2} \\
\text { to times more dilute (ref. 14) }\end{array}$ \\
\hline \multirow{2}{*}{$\begin{array}{l}\text { Polymers of sugars, amino } \\
\text { acids, or nucleotides }\end{array}$} & Immunoassay & $\begin{array}{l}\text { Specific compounds at } \\
10^{-18}-10^{-12} \mathrm{~g} \mathrm{~g}^{-1} \text { (ref. 15) }\end{array}$ & $\begin{array}{l}\text { Specific compounds at }>0.1-1 \\
\mu \mathrm{g} \mathrm{g}^{-1} \text { (ref. 16) }\end{array}$ & $\begin{array}{l}>1 \mathrm{mg} \text { (sample return); > } \\
1-10 \mathrm{~g} \text { (in situ), assuming } 25 \\
\text { fg protein cell }^{-1} \text { (ref. 17) }\end{array}$ \\
\hline & $\begin{array}{l}\text { Matrix assisted laser } \\
\text { desorption/ionization mass } \\
\text { spectrometry (MALDI) }\end{array}$ & $\begin{array}{l}\text { Compounds at } \leq 10^{-11}{\mathrm{~g} \mu \mathrm{m}^{-2}} \\
\text { (ref. 18). Imaging at } \mu \mathrm{m} \\
\text { scale (ref. 19). }\end{array}$ & $\begin{array}{l}\text { LDI only, }<10^{3} \text { amu (ref. 2) }(< \\
\text { 10-mer). Sensitivity } 1 \mathrm{ng} \mathrm{g}^{-1} \text {. }\end{array}$ & $\begin{array}{l}\text { > } 10 \mathrm{mg} \text { (sample return) (ref. } \\
18,19) ;>1 \mathrm{~g} \text { (in situ LDI) (ref. } \\
\text { 2) based on laser spot sizes. }\end{array}$ \\
\hline \multirow{6}{*}{$\begin{array}{l}\text { Morphologies resembling } \\
\text { microbial cells co-located } \\
\text { with physical activity, } \\
\text { textures, or compositions } \\
\text { distinct from the } \\
\text { environmental background }\end{array}$} & Atomic force microscopy & $\begin{array}{l}\text { Atom by atom imaging, } \\
\text { force spectroscopy }\end{array}$ & $\begin{array}{l}\mathrm{nm} \text {-scale imaging, } \mu \mathrm{m} \text {-scale } \\
\text { field of view (ref. 20). No force } \\
\text { spectroscopy yet (ref. 1,21). }\end{array}$ & $>1 \mathrm{~g}$ (assuming 100 cells $\left.\mathrm{g}^{-1}\right)$ \\
\hline & Optical microscopy & $\begin{array}{l}\mu \mathrm{m} \text {-scale imaging, } 0.5 \mathrm{~mm} \\
\text { field of view (FoV). UV } \\
\text { fluorescence. }\end{array}$ & $\begin{array}{l}\mu m \text {-scale imaging, FoV } 0.5 \\
\text { mm. UV fluorescence with UV } \\
\text { light source (ref. 1,22,23). }\end{array}$ & $>1 \mathrm{~g}$ (assuming 100 cells $\left.\mathrm{g}^{-1}\right)$ \\
\hline & $\begin{array}{l}\text { Digital holographic } \\
\text { microscopy }\end{array}$ & $\begin{array}{l}\text { No motility measurements } \\
\text { possible if no live cells }\end{array}$ & $\begin{array}{l}\text { Motion rate, direction. } \mu \mathrm{m}- \\
\text { imaging, FoV } 0.5 \mathrm{~mm} \text { (ref. 23) }\end{array}$ & $>1 \mathrm{~g}$ (assuming 100 cells $\mathrm{g}^{-1}$ ) \\
\hline & MALDI imaging & $\begin{array}{l}\mu m \text {-scale organic composition } \\
\text { maps to } 10^{4}-10^{5} \text { amu (ref. 19) }\end{array}$ & No mapping capability & < 1 ng (sub-mm grains) \\
\hline & $\begin{array}{l}\text { Atom probe tomography; } \mathrm{e}^{-} \\
\text {microscopy / X-ray spectro. }\end{array}$ & $\begin{array}{l}\text { Elemental maps from } \mu \mathrm{m} \text { to } \\
\text { sub-nm scales (ref. } 24,25 \text { ) }\end{array}$ & Cannot be flown & < 1 ng (sub-mm grains) \\
\hline & $\begin{array}{l}\text { [Nanoscale-] secondary ion } \\
\text { mass spectrometry (SIMS) }\end{array}$ & $\begin{array}{l}\text { Isotopic maps to sub- } \mu \mathrm{m} \\
\text { scales (ref. 25) }\end{array}$ & Cannot be flown & < 1 ng (sub-mm grains) \\
\hline
\end{tabular}




\begin{tabular}{|c|c|c|c|c|}
\hline \multirow{3}{*}{$\begin{array}{l}\text { Isotopic fractionation in } \\
\text { organic compounds and } \\
\text { inorganic species }\end{array}$} & Orbitrap mass spectrometry & \multirow{2}{*}{$\begin{array}{l}\text { Isotopic ratios to } 5 \% \text { of } \mathrm{C}, \mathrm{N} \\
\mathrm{S} \text { and if possible } \mathrm{H} \text { and } \mathrm{O} \text { in } \\
\text { specific organic compounds at } \\
\geq 0.1 \mu \mathrm{mol} \mathrm{g}^{-1}(\approx 10 \mathrm{ppm})\end{array}$} & \multirow{2}{*}{$\begin{array}{l}\text { Orbitrap being developed for } \\
\text { flight (ref. 26). Wet } \\
\text { chemistry/GC-c-IRMS not yet } \\
\text { developed for flight. }\end{array}$} & \multirow[b]{2}{*}{$\begin{array}{l}0.1 \mathrm{~g}(\text { for } \mathrm{C}), 0.25 \mathrm{~g} \text { (for } \mathrm{N} \text { ) for } \\
0.1-\mathrm{nmol} \text { limit of detection (ref. } \\
1,27)\end{array}$} \\
\hline & $\begin{array}{l}\text { Wet chemistry + Gas } \\
\text { chromatography - combustion } \\
\text { - isotope ratio mass spec. }\end{array}$ & & & \\
\hline & $\begin{array}{l}\text { Inductively coupled plasma } \\
\text { mass spectrometry, SIMS }\end{array}$ & $\begin{array}{l}{ }^{54} \mathrm{Fe} e^{56} \mathrm{Fe} \text { to } 0.1 \% \text { precision } \\
\text { vs. Fe abundance (ref. } 28 \text { ). }\end{array}$ & $\begin{array}{l}\text { ICP-MS not yet developed for } \\
\text { flight. SIMS cannot be flown. }\end{array}$ & < 1 mg (sample return) \\
\hline $\begin{array}{l}\text { Co-located oxidants and } \\
\text { reductants }\end{array}$ & $\begin{array}{l}\text { X-ray diffractometry; Infrared / } \\
\text { Raman spectro.; Imaging } \\
\text { mass spec.; a-particle X-ray } \\
\text { spectrometry; Laser-induced } \\
\text { breakdown spec. }\end{array}$ & $\begin{array}{l}\text { Maps of organic and inorganic } \\
\text { species }<10^{4}-10^{5} \text { amu at } \mu \mathrm{m} \\
\text { to } \mathrm{nm} \text {-scale. Minerals at }>5 \\
\text { vol\%. Organic and mineral } \\
\text { crystal structures. }\end{array}$ & $\begin{array}{l}\text { Maps of organic and inorganic } \\
\text { species }<500 \text { amu (ref. 1) at } \\
\text { sub-mm scales. Minerals at }> \\
5 \text { vol\%. }\end{array}$ & $\begin{array}{l}<<1 \mathrm{~g} \text { (sample return); } \\
\leq 1 \mathrm{~g} \text { (in situ) (ref. } 29,30) \text {. No } \\
\text { sample needed for in situ } \\
\text { infrared spectroscopy at close } \\
\text { range. }\end{array}$ \\
\hline $\begin{array}{l}\text { Inventory of species differing } \\
\text { from abiotic thermodynamic } \\
\text { equilibrium or steady state }\end{array}$ & \multicolumn{4}{|c|}{$\begin{array}{l}\text { Same as } \\
\begin{array}{c}\text { Distribution of the number of types of operations needed to obtain each molecule in the pool of detected organic compounds } \\
\text { and Co-located oxidants and reductants }\end{array}\end{array}$} \\
\hline
\end{tabular}

Table 2. Life detection capabilities and sample needed. Red: no capability; orange: in progress; bold: Earth capability exceeds that in situ by orders of magnitude. References listed at the end.

Milligrams (a few flybys) may be enough. The sample needed is partly constrained by the plume's sub-percent organic content. It also hinges on the ill-constrained possible biomass density; in Table 2 a plausible 100 cells $\mathrm{mL}^{-1}$ is assumed (Hand et al. 2017; Cable et al. 2020). In situ, the sample needed is several grams. This excludes use of the nanopore and assumes measurements are repeated (Lorenz 2019). In returned samples, only milligrams may be needed (Table 2). Because a $1 \mathrm{~m}^{2}$ area flown through the plume at $50 \mathrm{~km}$ altitude is expected to collect on the order of $3 \mathrm{mg}$ (Porco et al. 2017), in situ analyses require hundreds of flybys by a Saturn or Enceladus orbiter or a landed mission, whereas one flyby may suffice for a sample return.

Mission architectures capable of returning milligrams of sample are compared in Table 3.

\begin{tabular}{|c|c|c|c|c|c|}
\hline & $\begin{array}{c}\text { SUN ORBITER } \\
1 \text { flyby (no contingency) }\end{array}$ & $\begin{array}{l}\text { SATURN ORBITER } \\
\approx 15 \text { flybys year }^{1}\end{array}$ & $\begin{array}{l}\text { ENCELADUS ORBITER } \\
2 \text { flybys day }{ }^{1}\end{array}$ & CATCHING LANDER & $\begin{array}{l}\text { SURFACE SAMPLING } \\
\text { LANDER }\end{array}$ \\
\hline Collection rate & $0.003 \mathrm{~g} \mathrm{~m}^{-2}$ in total & $0.045 \mathrm{~g} \mathrm{~m}^{-2}$ year $^{-1}$ & $2 \mathrm{~g} \mathrm{~m}^{-2}$ year $^{-1}$ & $100 \mathrm{~g} \mathrm{~m}^{-2} \mathrm{y}^{-1}$ near stripes & $3.5 \mathrm{~g} \mathrm{day}^{-1}$ \\
\hline Collection velocity & $\sim \mathrm{km} \mathrm{s}^{-1}$ & $\sim \mathrm{km} \mathrm{s}^{-1}$ & $\begin{array}{l}250 \mathrm{~m} \mathrm{~s}^{-1} \text { (orbital speed + } \\
\text { plume particle speed; ref. 1). }\end{array}$ & $\leq 150 \mathrm{~m} \mathrm{~s}^{-1}$ (ref. 1) & $\begin{array}{l}\text { Fallback at } \leq 150 \mathrm{~m} \mathrm{~s}^{-1} \\
\text { experienced by material }\end{array}$ \\
\hline Age since ejection & \multicolumn{3}{|c|}{$<5 \min \left(\lesssim 50 \mathrm{~km} / 0.15 \mathrm{~km} \mathrm{~s}^{-1}\right)$} & $<5-10 \min$ & $>10$ years \\
\hline Access to neg. control ${ }^{2}$ & No & \multicolumn{2}{|c|}{ Depends on understanding of individual jet sources } & No (unless mobile) & Limited by reach/mobility \\
\hline $\begin{array}{l}\text { Rationale for collection } \\
\text { rate }\end{array}$ & \multicolumn{2}{|c|}{$3( \pm 2.5) \mathrm{mg} \mathrm{m}^{-2}$ per flyby at $50 \mathrm{~km}$ altitude (ref. } & $\begin{array}{c}3( \pm 2.5) \mathrm{mg} \mathrm{m}^{-2} \text { per flyby at } \\
50 \mathrm{~km} \text { altitude (ref. 1). } 2 \\
\text { flybys per day (ref. 3). }\end{array}$ & $\begin{array}{l}>0.1 \mathrm{~mm}_{\text {year }}^{-1} \text { near } \\
\text { tiger stripes (ref. } 4)\end{array}$ & $\begin{array}{l}10 \text { g per scoop every } \\
\text { other day (ref. 5). Age } \\
\text { based on fallback rate. }\end{array}$ \\
\hline Mission $\Delta \mathbf{v}$ & $\approx 0$ & $\sim 3 \mathrm{~km} \mathrm{~s}^{-1}$ (ref. 6) & $\begin{array}{l}\sim 4.5 \mathrm{~km} \mathrm{~s}^{-1}(2 \times \text { ref. } 5 \Delta \mathrm{v} \\
\text { budget in Saturn system) }\end{array}$ & \multicolumn{2}{|c|}{$\begin{array}{l}\sim 5 \mathrm{~km} \mathrm{~s}^{-1}\left(\text { Orbiter } \Delta v+\approx 2^{*} \Delta v \text { from/to halo orbit with }\right. \\
\text { semimajor axis } 500 \mathrm{~km})(\text { refs. } 3,7)\end{array}$} \\
\hline $\begin{array}{l}\text { Mission duration } \\
\text { (launch to reentry) }\end{array}$ & 25-34 years (ref. 8) & $\begin{array}{c}13-15 \text { years } \\
\text { possible (ref. } 6)\end{array}$ & \multicolumn{3}{|c|}{$\begin{array}{l}\geq 26 \text { years (ref. } 8,2 \times \text { ref. } 7 \text { ) due to prolonged pump-down in the Saturn system } \\
\text { (gravity assists from Titan, Rhea, Dione, Tethys; or electric propulsion) }\end{array}$} \\
\hline
\end{tabular}

Table 3. Architecture trades. Simpler options have less time at Enceladus, do less contextual science, and collect samples at higher speed. References listed at the end.

Traded quantities are mission duration, $\Delta \mathrm{v}$ (fuel mass, cost), and sampling velocity (to minimize changes to the sample upon collection), whereas sampling altitude is set by navigation uncertainty. Missions are all longer than the $\approx 15$ years for which spacecraft parts are qualified, save for the Saturn orbiter option. That option leads to the highest collection speeds $\left(\mathrm{km} \mathrm{s}^{-1}\right)$. Although gentler capture by orbiters and landers is preferred, even at $\mathrm{km} \mathrm{s}^{-1}$ molecules up to small chains of monomers survive impact if encased in ice grains (Burchell et al. 2014) because 
much of the impact kinetic energy is consumed in sublimating the ice. A few percent of (dead) cells can withstand ejection (Bywaters et al. 2020). Whether they withstand sampling at $>100 \mathrm{~m} \mathrm{~s}^{-1}$ is unknown. The merits of architectures are further discussed in the Enceladus PMCS report.

\section{Addressing challenges germane to sample return}

Samples are altered between their synthesis and their measurement (Fig. 3). Some alteration steps are natural (\#1-3 in Fig. 3). Understanding them requires understanding the sample's geological context, which on returned samples is only accessible at scales smaller than the sample. The other steps can be controlled. Steps \#5-9 are specific to sample return.

Figure 3. Steps altering samples between their synthesis in Enceladus' ocean and their measurement in the laboratory.

Understanding the geological context. An in situ study of plume material would establish a necessary baseline from which any alterations due to sample return can be identified. This makes an in situ mission (Lunine et al. 2015; Eigenbrode et al. 2018; MacKenzie et al. PMCS

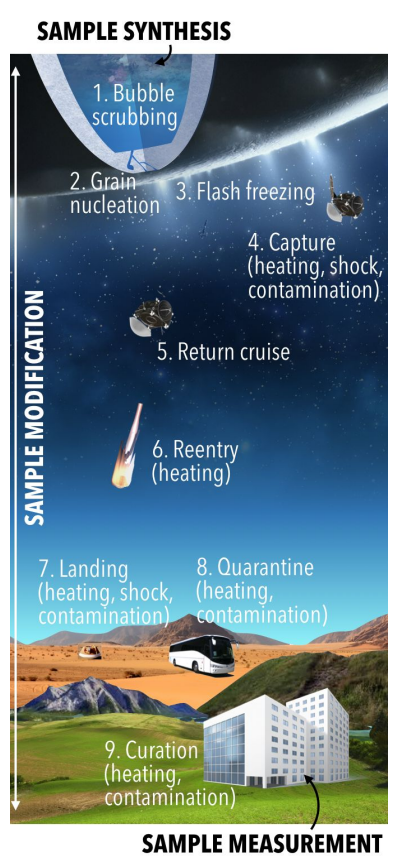
report) a logical precursor to sample return (Fig. 4) unless the in situ study is done by the sample return mission. The latter approach may be sensible given long trip times to Enceladus.

Figure 4. Paths for the astrobiological exploration of Enceladus. Steps may be bypassed (dashed arrows) based on changing knowledge and the design and findings of future missions. Modified from Sherwood (2016).

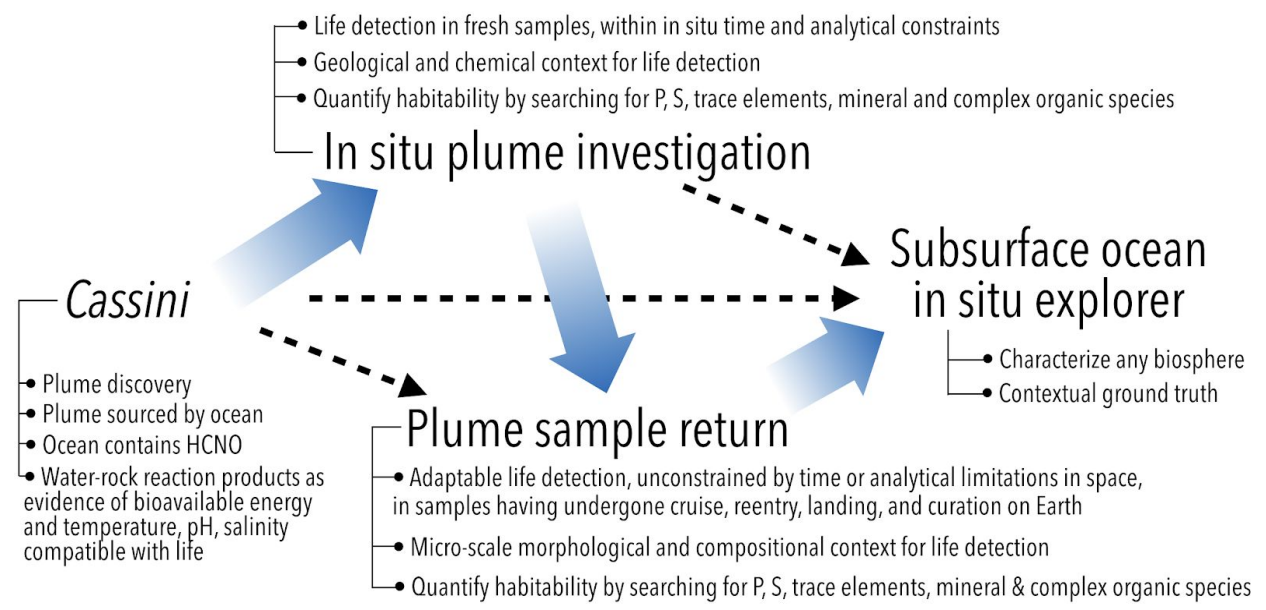

Minimizing sample alteration between capture and measurement. The plume contains water and other volatile species, silicate grains, organic compounds up to (at least) $\sim 10^{3}$ amu, and noble gases. Each component may require specific handling. We focus on plume solids (Table 2).

Collection. Low-density aerogel can capture this material at $\mathrm{km} \mathrm{s}^{-1}$ and preserve it (Sandford et al. 2006; Elsila et al. 2009; Carr et al. 2014). However, aerogel also traps organic contaminants. Both are dispersed in the aerogel matrix, complicating recovery and making aerogel a high-organic background material. Likewise, stacks of thin metal foils can capture particles relatively gently but share with aerogel the difficulty of extracting the sample. On solid metal (e.g., Al, Au, stainless steel, or Ti) collectors, contamination is more easily removed chemically or thermally. Retaining compounds freed from ice upon impact requires deposition on secondary surfaces (Aksyonov \& Williams 2001). These could be set up for robotic insertion into analytical 
instruments upon return, minimizing exposure to Earth contaminants. They could also be patterned so the diffuse sample layer can be concentrated into small spots prior to analysis.

Preservation through reentry. In the return cruise, radiation accumulates and an increasing solar flux warms the capsule, but the highest thermal and mechanical stresses occur at reentry and (possibly impact) landing. Refractory (thermally tolerant) and gas (mechanically resilient) sample fractions may be separated prior to reentry to tailor stress mitigation for each (Lunine et al. 2018). However, there is no ready approach to preserving ices sensitive to both stresses. Thermal mitigations include passive or active cooling and/or phase change materials.

Contamination mitigation includes cleaning the collector and capsule before launch, vacuum bakeout of the collector in space, protecting the collector from recontamination prior to and after sample collection, using witness materials that share the collector's composition and geometry, and outgassing and exposing these to space radiation prior to sampling (e.g., Summons et al. 2014). During reentry, keeping the collector cold mitigates volatile loss but enhances contamination from the atmosphere and outgassing of the capsule if a hermetic seal cannot be maintained. In curation, besides contamination inputs, the sample can lose volatile components. Levels of the amino acid glycine derived from a volatile precursor decreased by a factor $>6$ in Stardust foils stored at room temperature in a Class 5 cleanroom over 1000 days (Glavin et al. 2014). Contamination and volatile compound losses can be mitigated by sealing (Okazaki et al. 2017) and leak rate monitoring. Samples would likely be curated in conditions emulating the plume's cold vacuum.

Implementing Restricted Earth Return planetary protection policy. The COSPAR policy for Cat. V - Restricted missions (Kminek et al. 2017) is not quantitative. This allows flexibility in its implementation and means to check compliance but hampers preliminary design and costing. Quantitative requirements and means to check compliance could be specified for its provisions:

"Unless the samples [...] are steriliz[ed], the canister(s) [...] shall be closed, with an appropriate verification process, and the samples shall remain contained during all mission phases through transport to a receiving facility where it (they) can be opened under containment." A maximum leakage rate could be specified for particles of the size of the smallest known biological pathogens (10 to $15 \mathrm{~nm}$ for prions; Silveira et al. 2005), and tested with smaller tracers embedded in and monitored outside the sealed areas. Helium is commonly used, but its comparatively small van der Waals radius $(0.14 \mathrm{~nm})$ may be unnecessarily stringent.

"The mission [...] must provide a method to 'break the chain of contact' with [...] Enceladus. No uncontained hardware [...] shall be returned to the Earth's biosphere or the Moon. Isolation [...] shall be provided during [all] transfer operations [...]." This could require that uncontained parts in contact with the plume be jettisoned prior to or sterilized during reentry (actively or passively by, e.g., ambient radiation). Maximum probabilities of impact of unconfined parts on the Earth or the Moon, or of microbial survival on such parts, could be specified.

"For unsterilized samples returned to Earth, a program of life detection and biohazard testing, or a proven sterilization process, shall be undertaken as an absolute precondition for the controlled distribution of any portion of the sample." The policy could specify at which mission stages this program could take place. A first option is within the capsule just after capture (Yano et al. 2016a). A second is post-recovery of the capsule on Earth but prior to breaking the seal, either by outfitting the capsule with optical waveguides or puncturable interfaces (Yano et al. 
2016b), or by using non-contact techniques such as X-ray computed tomography (Takano et al. 2014; Zeigler et al. 2019). Life detection after opening the capsule but prior to distributing the sample could take place onboard a research ship confined in international waters (Takano et al. 2014). The policy could also list proven methods of sterilization.

Providing this detail either in the policy or in vetted documentation (e.g., NASA Procedural Requirement $8020.12 \mathrm{D}$ that implements the COSPAR policy), and allowing other approaches that equivalently achieve compliance, would advance astrobiology sample return.

References: Aksyonov \& Williams (2001) Rapid Comm Mass Spec 15:2001 • Burchell (2006) Int $J$ Astrobio 5:243 • Burchell et al. (2014) Astrobio 14:473 • Cable et al. (2020) in Planetary Astrobiology, UA Press • Bywaters et al. (2020) Life 10:40. • Eigenbrode et al. (2018) COSPAR

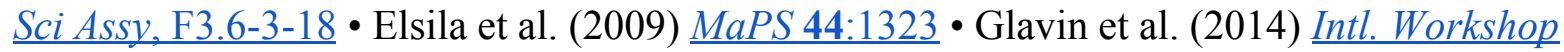
Instru Planet Missions, 1012 - Glavin et al. (2019) Chem Rev, in press. Hand et al. (2017) Europa Lander SDT Report • Hendrix, Hurford et al. (2019) Astrobio 19:1 • Kirk et al. (1995) in Neptune and Triton, UA Press, p. $949 \cdot$ Kminek et al. (2017) COSPAR's Planetary Protection $\underline{\text { Policy } ・ K u ̈ p p e r s ~ e t ~ a l . ~(2014) ~ N a t u r e ~ 505: 525 ~ • ~ L o r e n z ~(2019) ~ N a t ~ A s t r o n ~ 3: 466 ~ • ~ L u n i n e ~ e t ~ a l . ~}$ (2015) EGU 17:14923 • Lunine et al. (2018) EPSC abstr. 122 • MacKenzie et al. (2016) $\underline{A d v ~ S p}$ $\underline{\text { Res 58:1117 }}$ - MacKenzie et al. PMCS Report • McKay et al. (1996) Science 273:924 • Neveu et al. (2018) Astrobio 18: 1375 • Okazaki et al. (2017) Sp Sci Rev 208:107 • Porco et al. (2017) Astrobio 17:876 - Postberg et al. (2018) in Enceladus and the Icy Moons of Saturn, UA Press, p. 129 • Priscu et al. (1999) Science 286:2141 • Roth et al. (2014) Science 343:171 • Sandford et al. (2006) Science 314:1720 • Schopf (1993) Science 260:640 • Sekine et al. (2014) Trans Jpn Soc Aero Sp Sci 12:7 • Shearer \& Borg (2006) Chem Erde-Geochem 66:163 • Sherwood et al. (2016) Acta Astro 126:52 • Silveira et al. (2005) Nature 437:257 • Summons et al. (2014) Astrobiology $\underline{\text { 14:969 }}$ • Takano et al. (2014) Adv Sp Res 53:1135 • Tsou et al. (2012) Astrobiology 12:730 • Worth et al. (2013) Astrobio 13:1155 • Yano et al. (2016a) COSPAR Sci Assy, B0.6-8-16 • Yano et al. (2016b) COSPAR Sci Assy, B0.6-3-16 • Zeigler et al. (2019) Elements 15:286.

Table 2: ${ }^{1}$ Hand et al. (2017). ${ }^{2}$ Goesmann et al. (2017) Astrobio 17:655. ${ }^{3}$ Koga \& Naraoka (2017) Sci Rep 7:636. ${ }^{4}$ Glavin et al. (2019). ${ }^{5}$ Freissinet et al. (2010) J Chromato A 1217:731. ${ }^{6}$ Burton et al. (2013) $\mathrm{MaPS} 48: 390 .{ }^{7}$ Assuming a ratio of amino acids to total ( $\approx$ dissolved) organic carbon of 1:200 (e.g., Lee \& Bada 1975, EPSL 26:61). ${ }^{8}$ Cooper \& Rios (2016) PNAS 113:E3322.

${ }^{9}$ Furukawa et al. (2019) PNAS 116:24440. ${ }^{10}$ Rezzonico (2014) Astrobio 14:344. ${ }^{11}$ Plesivkova et al. (2019) Wiley Int Rev: Forens Sci 1:e1323. ${ }^{12}$ Sutton et al. (2019) Sci Rep 9:5370. ${ }^{13}$ Collins et al. (2018) Comm Biol 1:185. ${ }^{14}$ Cable et al. (2020). ${ }^{15}$ Zhang et al. (2013) Adv Mat 25:3802. ${ }^{16}$ Parro et al. (2011) Astrobio 11:15. ${ }^{17}$ Zubkov et al. (1999) Appl Env Micr 65:3251. ${ }^{18}$ Cornett et al. (2007) Nat Meth 4:828. ${ }^{19}$ Guenther et al. (2010) Int J Mass Spec 294:7. ${ }^{20}$ Riedler et al. (2007) Sp Sci Rev 128:869. ${ }^{21}$ Bentley et al. (2016) Acta Astron 125:11. ${ }^{22}$ Hecht et al. (2008) JGR Planets 113:E00A22. ${ }^{23}$ Bedrossian et al. (2017) Astrobio 17:913. ${ }^{24}$ Branson et al. (2016) PNAS 113: 12934. ${ }^{25}$ Jin \& Bose (2019) Sci Adv 5:p.eeav8106. ${ }^{26}$ Selliez et al. (2019) Planet Sp Sci 170:42. ${ }^{27}$ Elsila et al. (2009). ${ }^{28}$ Johnson et al. (2008) AREPS 36:457. ${ }^{29}$ e.g., Nurul Abedin et al. (2018) Appl Opt 57:62. ${ }^{30}$ e.g., Blake et al. (2012) Sp Sci Rev 170:341.

Table 3: ${ }^{1}$ Porco et al. (2017). ${ }^{2}$ Lorenz (2019). ${ }^{3}$ Massarweh \& Cappuccio (2020) doi: 10.2514/6. 2020-0467. ${ }^{4}$ Southworth et al. (2019) Icarus 319:33. ${ }^{5}$ Hand et al. (2017). ${ }^{6}$ Tsou et al. (2012). ${ }^{7}$ Spencer et al. (2010) V\&V MCS Report. ${ }^{8}$ Sekine et al. (2014). 